\title{
ANGIOLYMPHOID HYPERPLASIA WITH EOSINOPHILIA.ACQUIRED PORT-WINE-STAIN-LIKE LESIONS: ATTEMPT AT TREATMENT WITH THE ARGON LASER
}

\author{
Krystyna A. Pasyk, MD, PhD, Evette N. Elsenety, MD, ${ }^{\star}$ and \\ Erik B. Schelbert
}

\begin{abstract}
An unusual case of angiolymphoid hyperplasia with eosinophilia (ALHE) simulating port-wine stain in a 50-year-old woman is reported. The lesions of ALHE are typically papules or subcutaneous masses that range from light pink to red-brown in color. In addition to the usual histologic findings of AL.HE, the biopsy in our patient showed some fibrin-like material and fibrous longspacing collagen on ultrastructural examination. This unusual lesion necessitates biopsy because the differential diagnosis includes port-wine stain, sarcoidosis, lupus erythematosus, and non-Hodgkin lymphoma (mycosis fungoides). Many different forms of treatment have been attempted for ALHE including radiotherapy, cytotoxic chemotherapy, corticosteroids, and antibiotics. The lesions in our patient responded to argon laser therapy and surgical excision, though there has been recurrence on the border of the treated area. Because laser energy is noncumulative in the tissues and effective in removing the lesions, we recommend it as the treatment of choice for these lesions. HEAD \& NECK SURGERY 10:269-279, 1988
\end{abstract}

\footnotetext{
Acknowledgments. The authors tharik Nirs Chery! Hassell and Mr. Augustine Ozobia for their technical assistance. ano Ms. Mary L. Harper for editing this manuscript. We are grateful to Dr Abert $H$. Menke. III. for performing the second surgical excision.

Presented at the American Sociely of Piasic and Reconstructive Surgoons. Los Angeles. CA. October 26-31. :936

From the Section of Plastic and Reconstrucive Surgery. Department of Surgery. University of Michigan Medica! Scnoo!. Arin Arbor. Michigan (Dr. Pasyk and Schelberi): and Ingham Necica. Center. Lansing. Michigan (Dr. Elsenety).

Address reprint requests $10 \mathrm{Dr}$. Pasyk at tre Section of Prastic and Reconstructive Surgery. $400 \mathrm{~N}$ Ingalls Burtorg. A G-0160. Box 0488. Ann Arbor, MI 48109

Accepled for publication September 3. 198:
}

$0148 \cdot 6403 / 1002^{\prime} 026950400: 11$

c: 1988 John Wiley \& Suns. Inc.
Angiolymphoid hyperplasia with eosinophilia (ALHE) is an uncommon acquired benign vascular lesion that appears most frequently in the head and neck region, particularly around or on the ears. ${ }^{1-3}$ This entity has been previously described under a variety of names, which creates nosologic confusion ${ }^{4-24}$ (Table 1 ).

To date, no consensus exists on whether Kimura's disease (reported in Oriental literature) and ALHE (reported in the European and U.S.A. literature) are identical conditions. Many authors have claimed that Kimura's disease and ALHE are the same, ${ }^{10,15,25-27}$ others have hesitated to include Kimura's disease in the group of ALHE, ${ }^{1+}$ and some have detailed numerous and significant differences in the clinical, histologic, and laboratory aspects of these two entities. ${ }^{17,21.28-33}$

The main differences between Kimura's disease and ALHE are listed in Table 2. Kimura's disease appeared in younger patients, mostly between the first and third decade. ${ }^{27,28,34}$ ALHE, on the other hand, was observed in older patients during the third-fifth decades. ${ }^{28}$ A major predilection for males ( $85 \%$ ) was found in Kimura's disease, ${ }^{9.17 .28 .29 .35}$ while $70 \%$ of patients with ALHE were females. ${ }^{34,35}$

Clinically, the skin lesions of Kimura's disease were very similar to those of ALHE. ${ }^{10.14 .2-}$ 
Table 1. Synonyms of vascular-inflammatory, tumor-like lesions of the skin.

\begin{tabular}{|c|c|c|}
\hline Authors & Year & Synonyms \\
\hline Kimura et al. ${ }^{4}$ & 1948 & Unusual granulation combined with hyperplastic changes of lymphatic tissues \\
\hline Winer and Levin ${ }^{5}$ & 1959 & Acquired vascular tumors of the skin in adults \\
\hline Cramer ${ }^{6}$ & 1962 & Multiplen eosinophilen Granulomen der Kopthaut \\
\hline Summerly and Wells ${ }^{7}$ & 1963 & Subcutaneous lymphoid hyperplasia with eosinophilia \\
\hline Peterson et al. ${ }^{8}$ & 1964 & Alypical pyogenic granuloma \\
\hline Kawada et al. ${ }^{9}$ & 1965 & Eosinophilic lymphiolliculosis of the skin (Kimura's disease) \\
\hline Wells and Whimster ${ }^{10}$ & 1969 & Subcutaneous angiolymphoid hyperplasia with eosinophilia \\
\hline $\begin{array}{l}\text { Wilson-Jones and } \\
\text { Bleehen }{ }^{11}\end{array}$ & 1969 & $\begin{array}{l}\text { Inflammatory angiomatous nodules with abnormal blood vessels (pseudo or atypical } \\
\text { pyogenic granuloma) }\end{array}$ \\
\hline Wilson-Jones and Marks ${ }^{12}$ & 1970 & Papular angioplasia \\
\hline Kandil $^{13}$ & 1970 & Dermal angiolymphoid hyperplasia with eosinophilia \\
\hline Mehregan and Shapiro ${ }^{14}$ & 1971 & Angiolymphoid hyperplasia with eosinophilia \\
\hline Reed and Terazakis ${ }^{15}$ & 1972 & Subcutaneous angioblastic lymphoid hyperplasia with eosinophilia \\
\hline Kitabatake et al. ${ }^{16}$ & 1972 & Eosinophilic granuloma of the soit tissue \\
\hline Rosai and Ackerman ${ }^{17}$ & 1974 & Intravenous atypical vascular proliferation \\
\hline Inada et al. ${ }^{18}$ & 1977 & Eosinophilic lymphfolliculosis of the skin \\
\hline Bendl et al. ${ }^{19}$ & 1977 & Nodular angioblastic hyperplasia with eosinophilia and lymphtolliculosis \\
\hline Eady and Wilson-Jones ${ }^{20}$ & 1977 & Psuedopyogenic granuloma \\
\hline Rosai et al. ${ }^{21}$ & 1979 & Histiocytoid hemangioma \\
\hline Chang and Chen ${ }^{22}$ & 1982 & Eosinophilic granuloma of lymph nodes and soft tissue \\
\hline Weber et ai. ${ }^{23}$ & 1982 & Bullose angiolymphoide Hyperplasie mit Eosinophilie \\
\hline Enzinger and Weiss ${ }^{24}$ & 1983 & Epithelioid hemangioma \\
\hline
\end{tabular}

They were soft, single or multiple red-brown papules, or subcutaneous tumors ${ }^{2,10,18}$ in the head and neck region. ${ }^{10,14,28}$ They were also observed on the trunk and in the axillary, cubital, or inguinal area. ${ }^{34,36}$ Lesions on the oral mucous membranes ${ }^{25,28,37-42}$ heart, ${ }^{43}$ penis, ${ }^{44}$ knee, ${ }^{45}$ and hands $\mathrm{s}^{46,47}$ were seen in a few cases of ALHE. The lesions of Kimura's disease were larger $(2-10 \mathrm{~cm})$ than those of ALHE $(0.2-6$ cm). ${ }^{24,27,28,34,36}$ The lesions in both entities were usually painless, but sometimes pruritus and pulsation were present. ${ }^{2,5,9,16,21}$ Regional lymphadenopathy was common in Kimura's disease $^{34,36}$ but it was unusual in ALHE. ${ }^{28}$

Histologically, the lesions in Kimura's disease were located more often in deep subcutaneous tissue ${ }^{34}$ rather than in the dermis, as in ALHE. ${ }^{2}$ The blood vessels in Kimura's disease were numerous and proliferative but not as prominent as in ALHE. ${ }^{2,9,17,21,29}$ In ALHE, the endothelial cells, which formed solid uncanalized masses, were large and slightly pleomorphic and or lined newly formed blood vessels. ${ }^{2,26,48}$ These endothelial cells possessed a large vesiculated nucleus with numerous fissures and prominent vacuolated cytoplasm resembling histiocytes. ${ }^{29}$ The inflammatory infiltrates of lymphocytes, eosinophils, and histiocytes were indistinguishable in the two conditions. ${ }^{11,21}$ In some cases of ALHE, however, tissue eosinophilia was ab- sent. ${ }^{2,48}$ Infiltrates of mast cells were more numerous in ALHE than in Kimura's disease. ${ }^{10,31,32}$ Nodular lymphoid follicles with germinal centers were almost always present in Kimura's disease ${ }^{30-32,49,50}$ but only sporadically noted in ALHE. ${ }^{31,32,51}$ In all stages of Kimura's disease there was marked fibrosis, ${ }^{31,32}$ but in ALHE fibrosis was absent. ${ }^{10,30}$

Blood eosinophilia was more prominent in Kimura's disease than in ALHE. ${ }^{27,52} \mathrm{~A}$ high serum level of $\operatorname{IgE}$ was present in Kimura's disease, ${ }^{18,30,34,50,53}$ while it was low in ALHE. ${ }^{25,27}$ IgE deposition within lymphoid follicles was usually noted in Kimura's disease ${ }^{18,34,54}$ but was present only in a few cases of ALHE. ${ }^{45,55}$ Iguchi et al. ${ }^{30}$ suggested that serum IgE level may be an important factor during differentiation of Kimura's disease and ALHE. Also, serum anti-Candida albicans antibody was reported in Kimura's disease, ${ }^{54}$ but only occasionally observed in ALHE. ${ }^{45,56}$ Skin tests for Candida in Kimura's disease were usually positive ${ }^{54}$ but negative in ALHE. ${ }^{27}$

The pathogenesis of ALHE remains unclear. Opinions are divided on whether the lesion represents a true neoplastic proliferation of blood vessels, ${ }^{11.21,29}$ a response to trauma, infection, and humoral imbalance, ${ }^{2}$ or a reactive process secondary to immunologic injury. ${ }^{56}$

Various methods of treatment for Kimuri's 
Table 2. Kimura's disease vs. angiolymphoid hyperplasia with eosinophilia.

ynonyms

First publication

occurrence

Sex

Jeographical distribution

Lumber of cases

clinical morphology

Size of lesions

Site of predilection

jymptoms

\section{: Histopathology Location of lesions \\ Blood vessels}

Infiltration

Lymphoid follicles

Fibrosis

Regional

lymphadenopathy

Peripheral eosinophilia

Serum IgE

Deposition of $\lg E$

Serum anti-Candida alb. antibody

Skin test with Candida

Course and prognosis
In the Oriental literature:

Eosinophilic lymphfolliculosis of the skin ${ }^{9}$

Eosinophilic granuloma of lymph nodes and soft tissue ${ }^{16.41}$

Kimura et al. $1948^{4}$

During the 1st to 3rd decade $27,28.32$

Mostly in males $(85 \%)^{9.28 .40}$

China, Southeast Asia, Japan

113 cases $^{36}$

Single or multiple red-brown papules or subcutaneous tumors ${ }^{10,18}$

\section{Larger than $2 \mathrm{~cm}$ in diameter ${ }^{28}$}

Head and neck area. May occur anywhere in the body ${ }^{17.28 .34}$

Localized or generalized pruritus ${ }^{9.16}$

Deep subculaneous tissue or dermis ${ }^{27}$

Moderate proliferation of capillaries. Large and thickened vessels with prominent endothelial cells without distinctive morphology 2.9 .17 .34

Intensive infiltrates of lymphocytes, eosinophils, and histiocytes; a few mast cells ${ }^{18.21 .37 .38}$

Hyperplasia of lymphoid tissue with germinal centers ${ }^{25.36-38.43}$

Marked fibrosis in all stages ${ }^{37.38}$

Common $^{27}$

Almost always present ${ }^{32}$

High level ${ }^{18,27,36.45 .46}$

Present within lymphoid follicles ${ }^{18.27 .45}$

Present ${ }^{45}$

Positive ${ }^{45}$

Long, good ${ }^{16}$
In the English literature:

Subcutaneous lymphoid hyperplasia with eosinophilia ${ }^{7}$

Subcutaneous angiolymphoid hyperplasia with eosinophilia ${ }^{10}$

Weils and Whimster $1969^{10}$

During the 3 rd to 5 th decade $\mathrm{e}^{28.32}$

More often in females $(70 \%)^{27,40}$

Europe and U.S.A.- in non-Oriental persons

$102 \operatorname{cases}^{28}$

Dome-shaped, light pink to red-brown papules or subcutaneous masses. Multiple lesions form a "grape-like"plaque ${ }^{2}$

Smaller than $2 \mathrm{~cm}$ in diameter ${ }^{28}$

Head and neck area in $86 \%$ of the cases ${ }^{28}$

Sometimes pruritus, pain, bleeding, and pulsation present 2.5 .21

Subcutis or dermis ${ }^{2}$

Abundant angiomatoid proliferation of capillaries with prominent endothelial cells. Solid,

uncanalized masses of histiocytoid endotheliat cells ${ }^{31,42}$ with a large, vesiculated, fissured. nucleus and a vacuolated cytoplasm. ${ }^{34}$ Large vessels with intravascular endothelial proifferation and cutaneous AV shunts ${ }^{2}$

Diffuse intiltrates of lymphocytes, eosinophils, and histiocytes; numerous mast cells ${ }^{10.37 .38}$

Sometimes a few lymphoid follicles usually without germinal centers ${ }^{37.38 .44}$

No fibrosis ${ }^{10.36}$

Unusual; present only in $11 \%$ of the cases ${ }^{28}$

Usually normal ${ }^{27}$

Low level ${ }^{29.32}$

Only in a few cases within lymphoid follicles ${ }^{30.47}$ Occasionally present ${ }^{35,47}$

Negative 27

Long, good ${ }^{2}$ disease and ALHE have been used, including (adiotherapy, ${ }^{11,16,28,30,57}$ systemic $^{15,23}$ or intralesional corticosteroids, ${ }^{27,41,58}$ antibiotics, ${ }^{23}$ cytooxic agents (vinblastine), ${ }^{42}$ retinoic acid, ${ }^{59}$ elecrodesiccation and curettage, ${ }^{14,58}$ surgical excision and grafting, ${ }^{28,30,46,60,61}$ and recently the $\mathrm{CO}_{2}$ laser $^{62}$ and the argon laser. ${ }^{34,42}$

We report here a case with atypical, flat lesions resembling port-wine stains in which light and electron microscopic and immunohistochemical studies revealed the features of ALHE. Treatment options, specifically laser therapy, of these rare, apparently benign lesions will be discussed.

\section{CASE REPORT}

Clinical Findings. A 50-year-old woman presented with two flat, port-wine-stain-like lesions on the right postauricular region and the neck (both $4 \times 2.5 \mathrm{~cm}$ in diameter). (Figures $1 \mathrm{~A}$ and $2 \mathrm{~A}$ ). These lesions appeared 5 years ago and slowly increased in size without any subjective symptoms or lymphadenopathy. Family history revealed that her father and her niece have portwine stains on the abdomen and face, respectively.

Routine laboratory examinations, including complete blood count and serum chemistry, were within normal limits. Biopsies of the lesions, on 


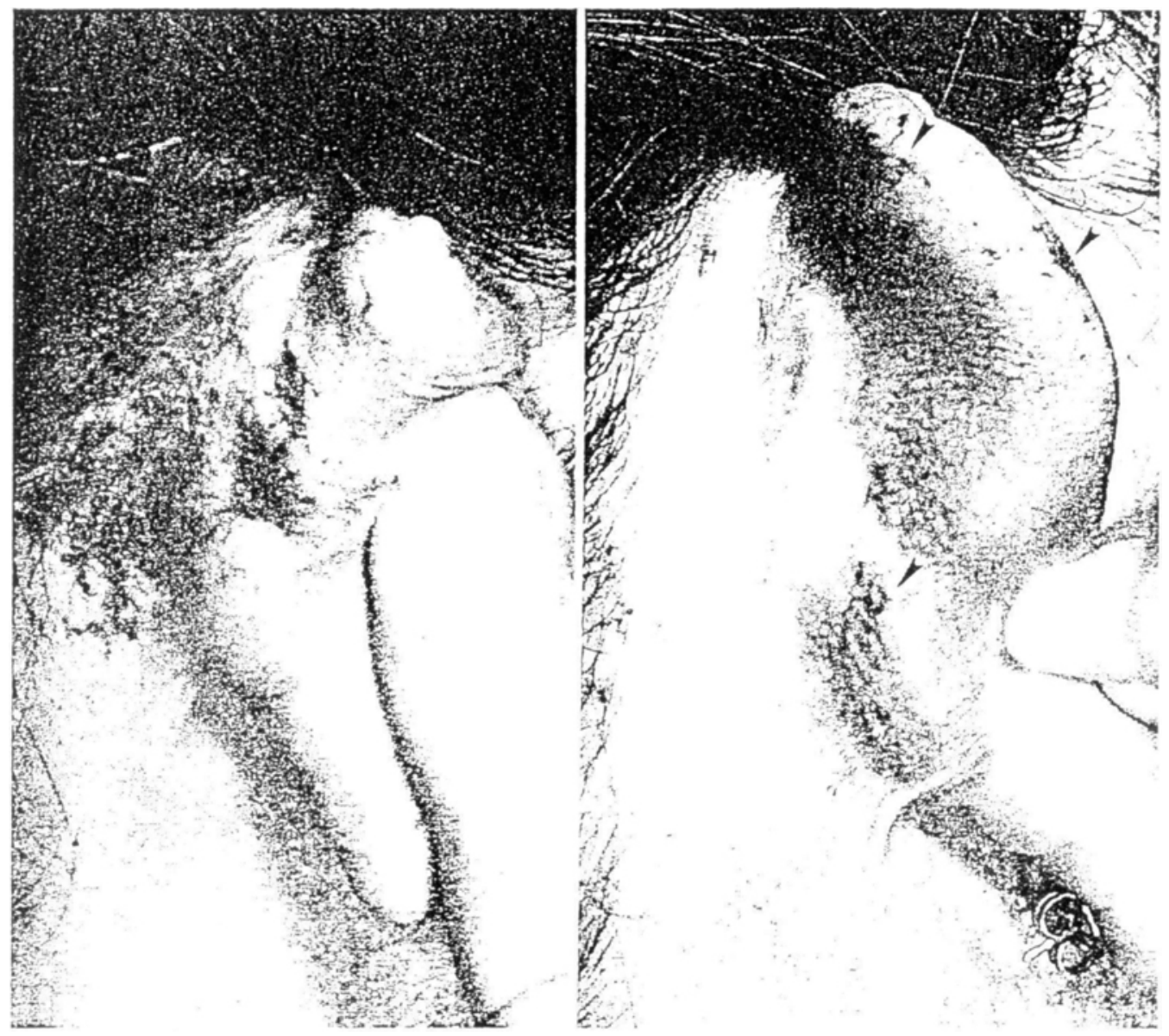

FIGURE 1. A 50-year-old woman with a flat, red lesion behind the ear simulating a port-wine stain. (A) Before treatment; (B) the same patient 17 months after argon laser surgery. Note telangiectatic vessels on the border of the treated area (arrowheads).

histopathologic examination, showed features that corresponded to criteria of ALHE.

Histopathology and Immunohistochemistry. The lesion was localized in the midportion of the dermis and was characterized by proliferation of blood vessels that were surrounded by a dense cellular infiltrate $\{$ Figure 31. Some dilated ressels formed tortuous, irregular channels. Others were uncanalized or only partially canalized. Thin-walled, dilated capillaries or lymphatic ressels and venules were lined by large endothelial cells, very similar to histiocytes and surrounded by lymphocytes. histiocytes. matst (cells. and a few eosinophils (Figura +1). Fucil extension of the "inflammatory" cellular infiltrate o the hatr follicles was also noted. There was no cellulate at pia or increased mituses in the enduhelium and infiltrating cells. Wilders stan demenstratted delicate reticular fibers surounding the hind res. sels, which were also visible within the cellular infiltrations.

Immunohistochemical study was performed on formalin-fixed tissue in paraffin sections using the immunoperoxidase technique for factor VIII-related antigen. The endothelial cytoplasm was faintly positive. Muramidase stain, a potential marker of histiocytes, was negative.

Electron Microscopy. Uiltrastructural examination showed vascular structures lined by plump endothelial cells that protruded into the lumen. These cells possessed convoluted or multilobulated nuclei and cytoplasm with relatively normal organelles including numerous filaments and sparse Weibel-Palade bodies. Many cytoplasmic protrusions were seen on the luminal surface of the endothelial cells (Figure 5A). The basal lamina was multilarered in some areas and absent in others. (Jccisional fenestrations of the 


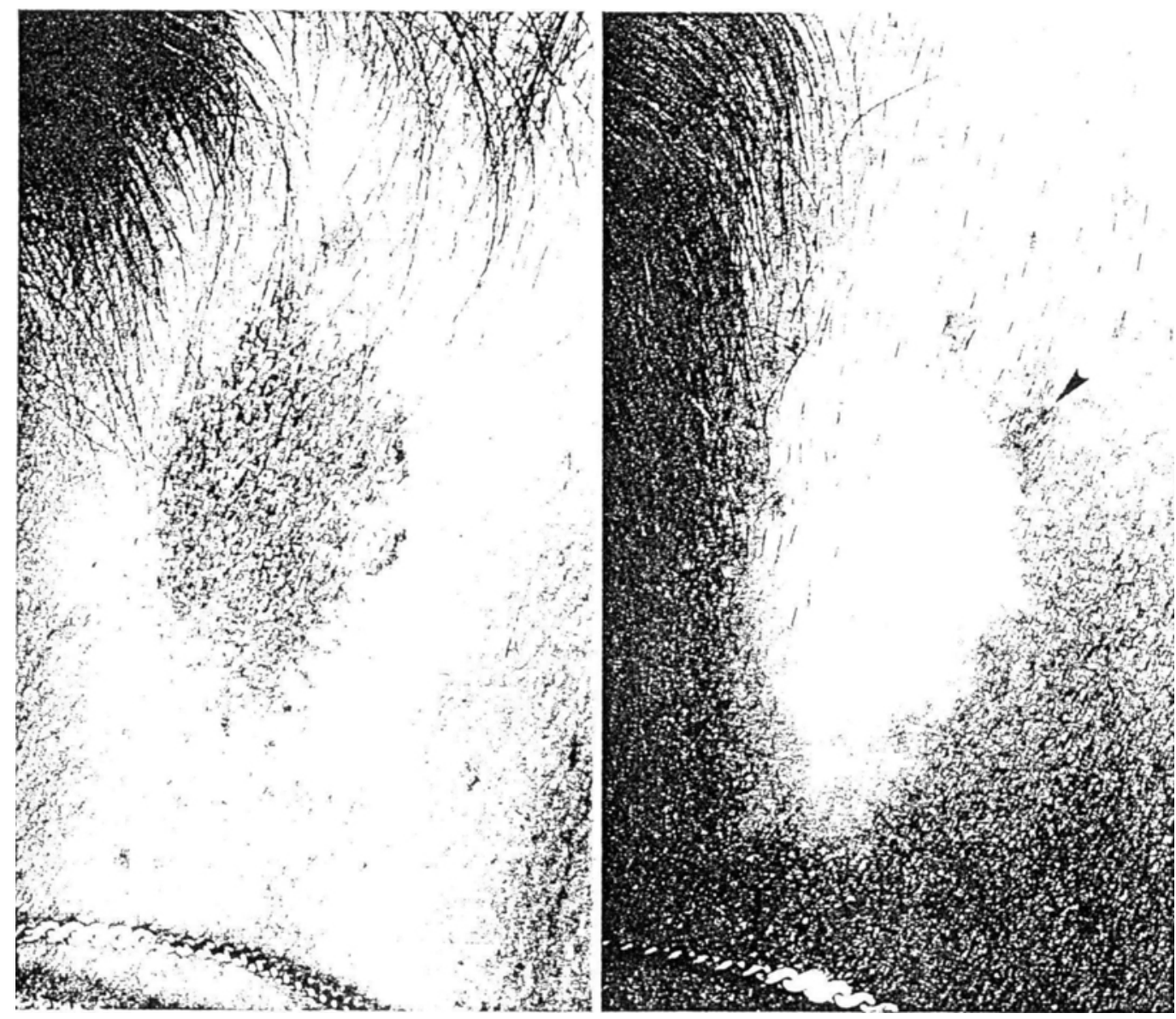

FIGURE 2. Port-wine-stain-like lesion on the neck in the same patient. (A) Before treatment: (B) after argon laser surgery showing new vascular lesions close to the treated area (arrowheads).

vessel walls were also found (Figure 5B). The mixture of histiocyte-like cells, lymphocytes, and mast cells were very close to the vessels. The histiocytoid cells formed solid clusters without formation of a lumen. Their nuclei were large and irregular with multiple indentations, dense rims of heterochromatin, and prominent nucleoli. The cytoplasm contained mitochondria, microtubules, microfilaments, abundant vacuoles, lysosomes, relatively large Golgi elements, and prominent smooth and rough endoplasmic reticulum. The cell surface possessed numerous folds and fingerlike processes. Stroma consisted of an amorphous substance, a few collagen fibers, reticular fibers, and fibrin-like material. Additionally, "banded structures" or fibrous long-spacing collagen were also observed (Figure 6 ).

Treatment. An argon laser iSystem 1000 Dermatologic Argon Laser. Coherent. Palo Alto.
CA) test treatment was performed using a power density of 153 watts $/ \mathrm{sq} \mathrm{cm}$ (exposure time $0.2 \mathrm{~s}$; power 1.3 watts; spot size $1 \mathrm{~mm}$ ) on an area $1.5 \times$ $1.5 \mathrm{~cm}$ under local anesthesia with $2 \%$ lidocaine without epinephrine. After 4 months, good results were observed in the tested area and the rest of the lesions were treated under similar laser conditions. The lesions received 1,847 exposures with a power density of 153 watts $/ \mathrm{sq} \mathrm{cm}$. On examination at 5 months and again at 1 year after treatment there were no lesions in the treated area. but, in some parts of the margin, new vessels were seen (Figures $1 B$ and $2 B$ ). They were coagulated, with the argon laser using the same power density as before. After 1 more year, lesions spreading from the border of the treated part were observed again. At this time, the lesions were excised and for the second time histologically examined. Nine months after excision, the patient nuted new vascular spots close to the 


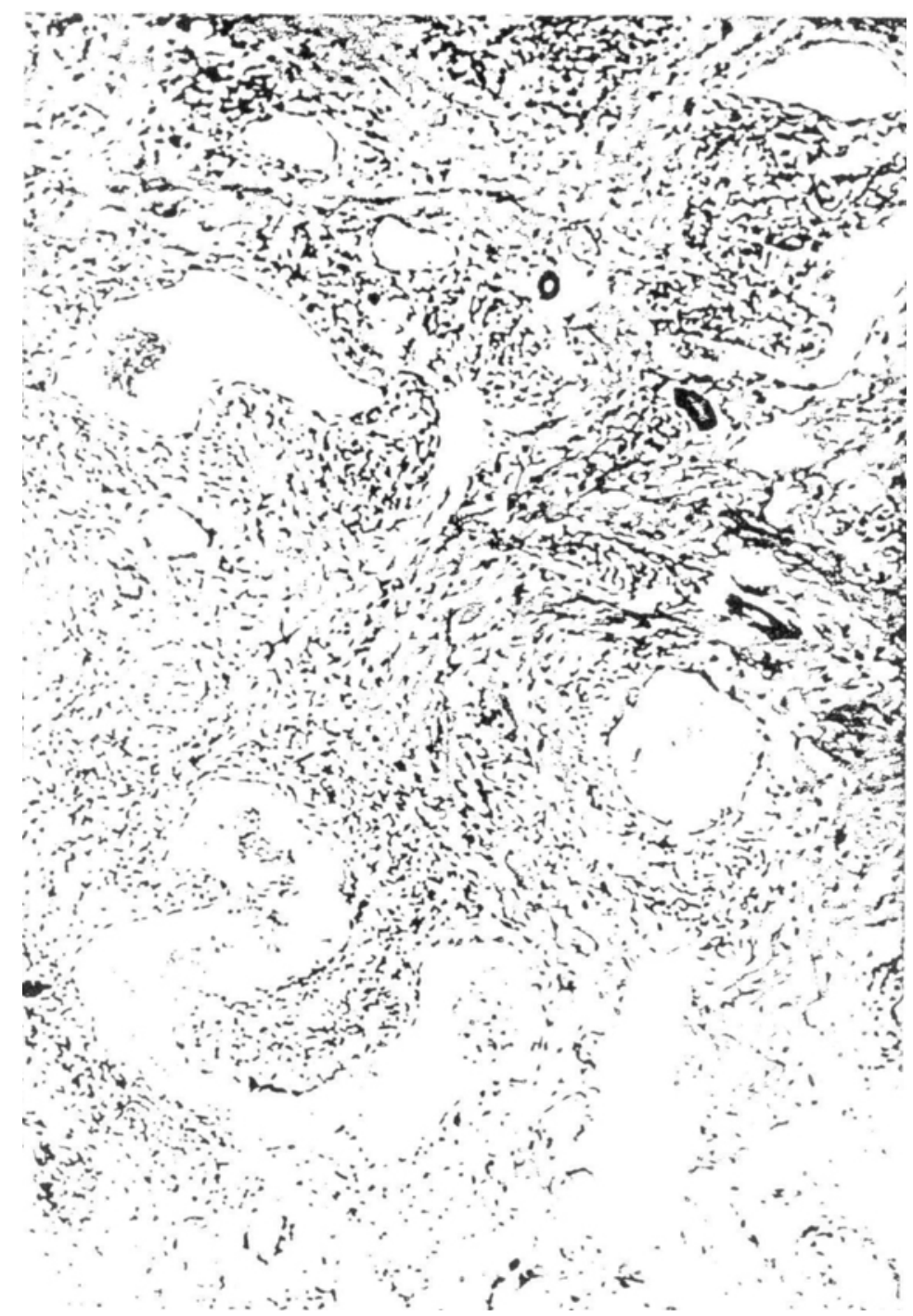

FIGURE 3. Micrograph of dilated, thin-walled blood vessels in the dermis. Note dense infiltration of lymphocytes and histiocytes very close to the vessels. Hematoxylin and eosin, Original magnification $\times 50$.

margin of the surgical scar and on the ear. These lesions will be treated with the argon laser using a higher power density than was used before.

\section{DISCUSSION}

The lesions in our patient were unusual in that they resembled port-wine stains rather than the tumor-like nodules that appear both in Kimura's disease and ALHE. Lesions similar to those of our patient were reported by Weber et al ${ }^{2: 3}$ to have occurred on the head in two patients. These lesions were also flat and pinkish-red, but recurred with bullous eruptions despite treatment with antibiotics and corticosteroids.
As in most reported cases with

ALHE. ${ }^{25.34 .48 .52}$ our patient did not have tissue and blood eosinophilia or peripheral lymphadenopathy. On light and electron microscopy, our patient's lesions possessed a histologic pattern characteristic of ALHE, which is the heading under which we prefer to classify these lesions. They were located in the midportion of dermis showing histiocytic-type endothelial cells and infiltration of lymphocytes. histiocytes, and mast cells. The presence of fibrin-like material and fibrous long-spacing collagen are new findings in $A L H E$ and they both require further study.

Immumoperoxidase technique for factor VIIIrelated antigen-a miltien for endothelial cells at the tissue level-demonstrated a weakly pos- 


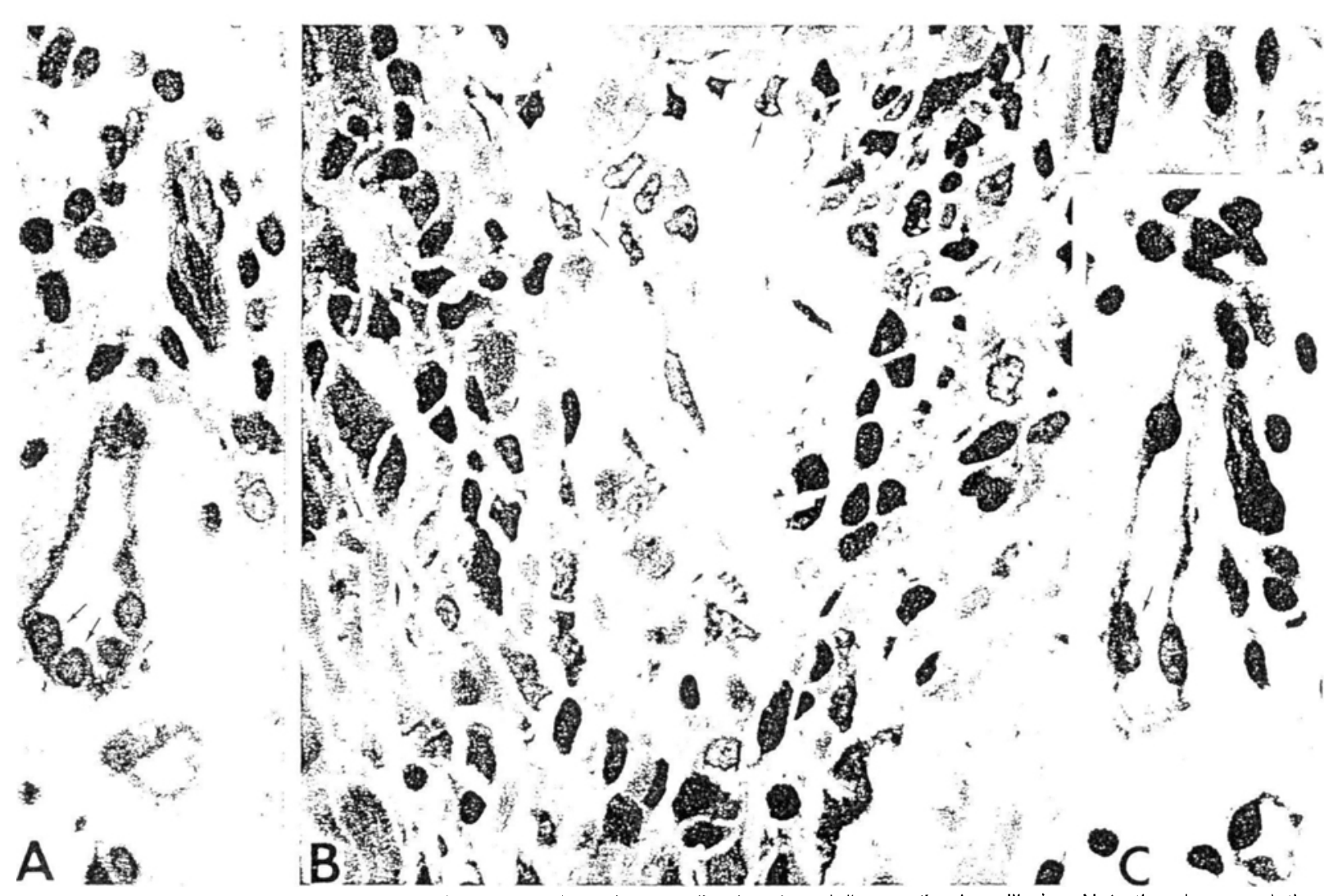

FIGURE 4. Micrographs (A,B,C) showing dilated vessels and uncanalized and partially canalized capiliaries. Note the plump endothelial cells resembling histiocytes (arrows). Epon, toluidine blue, Original magnification $\times 500$.

itive reaction in the endothelial cells. Variable positive staining of the proliferating endothelial cells for factor VIII-related antigen was also observed in ALHE by some authors, ${ }^{2.50}$ and in some malignant and benign vascular tumors. ${ }^{63.64}$ Ose et al. ${ }^{50}$ noted in their immunohistochemical study on histiocytoid hemangioma that the intensity of staining for factor VIIIivon Willebrand factor antigen decreased. False-negative results may be explained, however, by a high lability of factor VIII-related antigen, which may not survive routine formalin fixation and processing. ${ }^{65}$ An indirect immunoperoxidase procedure for the presence of lysozyme as a specific histiocytic marker was negative in $\mathrm{ALHE}^{+4 . n)}$ Results of our study with nuramidase stain were also negative.

The morphology of the lesion in ALHE seems to vary with duration. The lesions in an early phase display a higher degree of rascular proliferation and larger endothelial cells, while those of longr duration have more lymphoid tissue and a less prominent endothelium. 111.2.

The histogenesis of himurats discise and ALHE is still not eleatr. I)irece immumbllumes- cent studies of tissue with ALHE have shown deposits of IgA, IgM, and complement C3 around small vessels within the lesions. ${ }^{56}$ These data may indicate an immunologic phenomenon in this entity. Marsten ${ }^{66}$ has even postulated that ALHE represents an autoimmune disorder similar to that in Hashimoto's thyroiditis.

The course of ALHE is chronically progressive, though benign. Spontaneous resolution of lesions may occur after many months, ${ }^{10,12,13,15}$ but prolonged duration is more common. 14,67 Due to the nonspecific nature of the entity, it can be mistaken for a number of other conditions including malignant angioendothelioma, pyogenic granuloma, eosinophilic granuloma, angiomatous lymphoid hamartoma, granuloma faciale, Jessner's lymphocytic infiltrate, pseudolymphoma, atheroma, hemangioma, or persistent reaction to insect bites. ${ }^{2.111 .1+.25 .36 .49 .55}$ The flat, red lesions, as our patient presented, should be differentiated from port-wine stain, sarcoidosis, lupus erythematosus. and non-Hodgkin lymphoma such as mycosis fungroides. Hence, a biopsy is usually necessary to establish the diagnosis.

Many method: have been used to treat the 


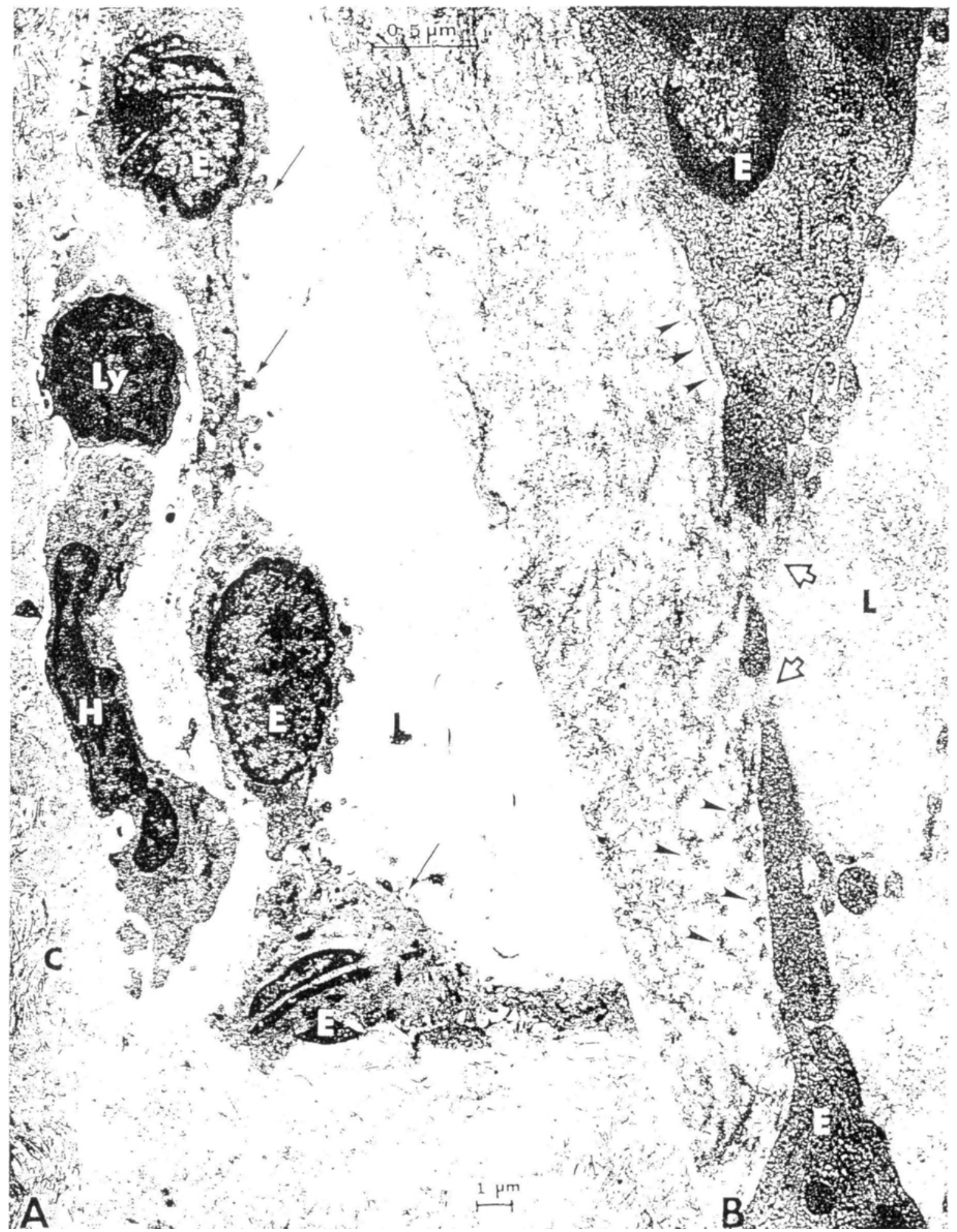

FIGURE 5. Electron micrograph (A). Dilated blood vessel with prominent endcthellal cells (E) and numerous cytoplasmic proections. especially on the lumina! surtaie larows). Lumen (L): basal lamina (arrowheacs! ymphocyle (Ly): histiocyle (H): col!agen ficers (C). Magnification $\cdot 36.250$. 


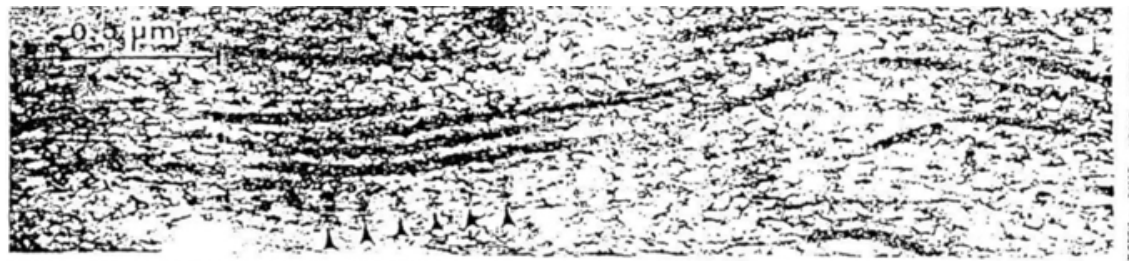

$$
\begin{aligned}
& \text { W }
\end{aligned}
$$

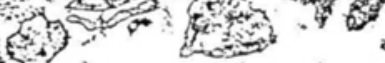

$$
\begin{aligned}
& \text { 政 }
\end{aligned}
$$

1.

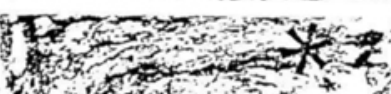

간, 褯 7. 1
$y$

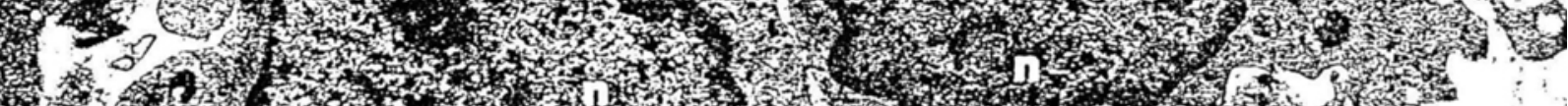

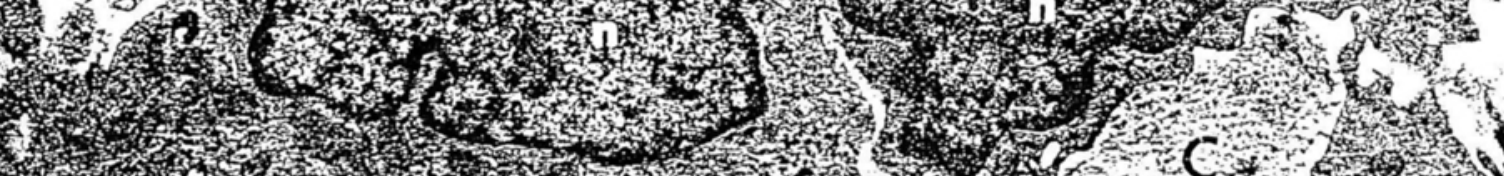

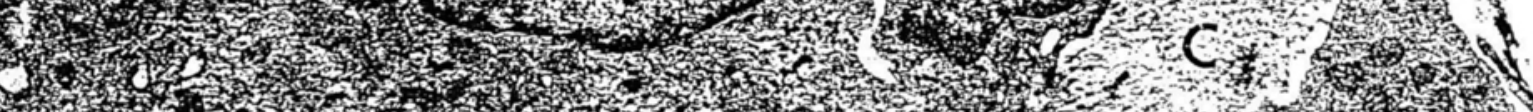

Y.7,

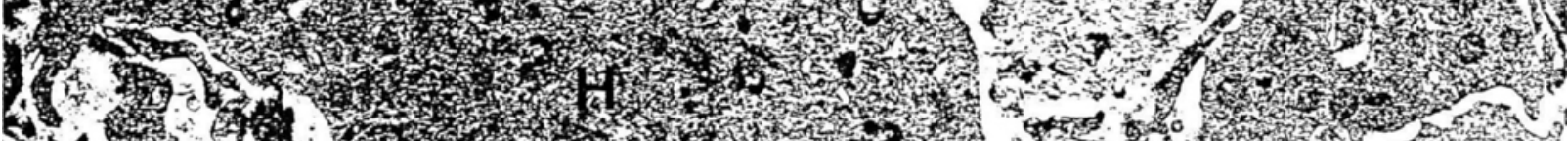

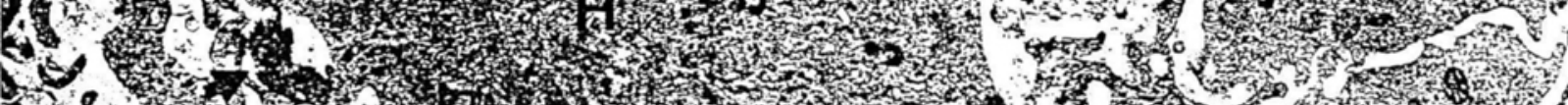

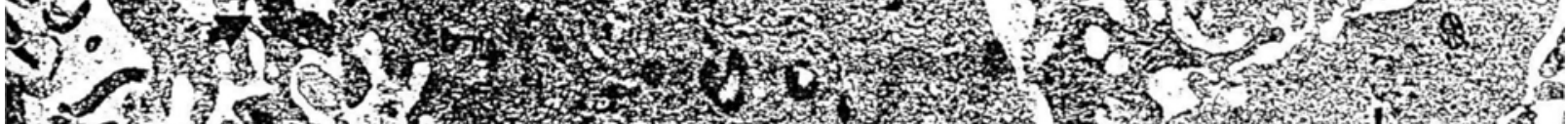
1.8.

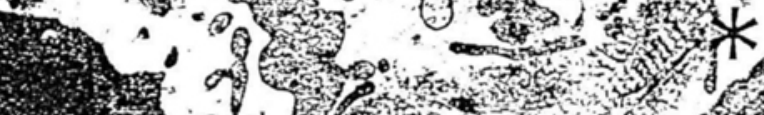
6.7.6.
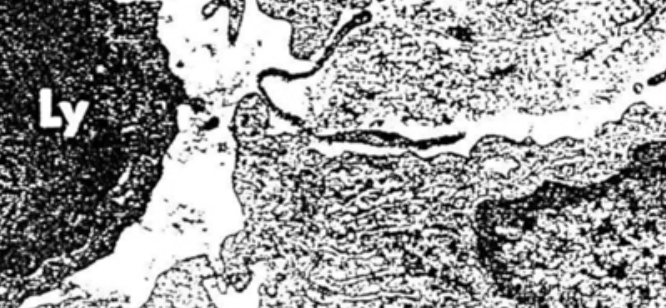<smiles>C1=C[As]2C[As]12</smiles>

ind

1.7.

W.

2.3. 
skin lesions in ALHE and Kimura's disease. Radiation therapy, while effective, poses long-term risks for the patient; its value in treating a relatively benign lesion is questionable. Antibiotics and steroids provide a less aggressive form of treatment, but many clinicians reported inconsistent results. ${ }^{13,23,55,68}$ Cytotoxic agents were rarely beneficial ${ }^{9,42}$ and their systemic toxicity needs to be taken into account in this benign disorder. ${ }^{69}$ Retinoic acid can reduce the size of lesions, but does not lead to complete regression. ${ }^{59}$ Excision of the lesions and laser surgery appear to be the treatments of choice, although some of the lesions did recur, as was the case in our patient. ${ }^{13,19,42,49,56,57}$ The red, vascular lesions were very easily coagulated by argon laser energy, but a few months later they started to spread from the margin of the treated areas. After surgical excision of the new lesions, spreading of dilated vessels was again observed. We intend to treat these lesions with the argon laser using a higher power density. The use of laser energy is more beneficial than surgical excision for two reasons. First, laser beams can easily coagulate or vaporize lesions that are located in areas very difficult to approach surgically, and second, because the laser energy is not cumulated in tissues; it may be used repeatedly for re-treatment of these recalcitrant lesions.

\section{REFERENCES}

1. Nix M: Angiolymphoid hyperplasia with eosinophilia in association with a vascular malformation. I Dermatol Surg Oncol 10:632-636, 1984.

2. Olsen TG, Helwig EB: Angiolymphoid hyperplasia with eosinophilia. A clinicopathologic study of 116 patients. $J$ Am Acad Dermatol 12:781-796, 1985.

3. Ferlito A, Caruso G: Angiolymphoid hyperplasia with eosinophilia of the external ear (Kimura's disease). Otorhinolaryngol 47:139-144, 1985.

4. Kimura T, Yoshimura S, Ishikawa E: On the unusual granulation combined with hyperplastic changes of lymphatic tissues. Trans Soc Pathol 37:179-180, 1948.

5. Winer LH, Levin GH: Acquired vascular tumors of the skin in the adult: a report of five unusual cases. Arch Dermatol 79:17-31, 1959.

6. Cramer HJ: Histologische Verlaufsuntersuchengen an multiplen "eosinophilen" Granulomen der Kopfhaut. $\mathrm{Ha}$ utarat 13:315-321, 1962.

7. Summerly R, Wells GC: Subcutaneous lymphoid hyperplasia with eosinophilia. Proc Roy Soc Med 56:728-729, 1963.

8. Peterson WC Jr, Fusaro RM, Goltz RW: Atypical pyogenic granuloma. Arch Dermatol 90:197-207, 1964.

9. Kawada A, Takahashi H, Anzai T: Eosinophilic lympholliculosis of the skin (Kimura's disease). Nippon Hifuka Gakkai Zasshi 76:61-72, 1965.

10. Well GC, Whimster IW: Subcutaneous angiolymphoid hyperplasia with eosinophilia. Br J Dermatol 81:1-15, 1969 .

11. Wilson-Jones $E$, Bleehen SS: Inflammatory angiomatous nodules with abnormal blood vessels occurring about the ears and scalp (pseudo or atypical pyogenic granuloma). Br J Dermatol 81:804-816, 1969.

12. Wilson-Jones E, Marks R: Papular angioplasia. Arch Dermatol 102:422-427, 1970.

13. Kandil E: Dermal angiolymphoid hyperplasia with eosinophilia versus pseudo-pyogenic granuloma. $\mathrm{Br} J$ Dermatol 83:405-408, 1970.

14. Mehregan AH, Shapiro L: Angiolymphoid hyperplasia with eosinophilia. Arch Dermatol 103:50-57, 1971

15. Reed RJ, Terazakis N: Subcutaneous angioblastic lymphoid hyperplasia with eosinophilia (Kimura's diseasel. Cancer 29:489;-497, 1972.

16. Kitabatake T, Kurokowa H, Kurokowa S, Terada I. Hirasawa K: Radiotherapy for eosinophilic granuloma of the soft tissue (Kimura's disease). Strahlentherapie $144: 407-413,1972$.
17. Rosai J, Ackerman LR: Intravenous atypical vascular proliferation; a cutaneous lesion simulating a malignant blood vessel tumor. Arch Dermatol 109:714-717, 1974.

18. Inada S, Yamamoto S, Kitaura H, Yamura T: A case of eosinophilic lymphfolliculosis of the skin (Kimura's dis ease). J Dermatol (Tokyo) 4:207-214, 1977.

19. Bendl BJ, Asano K, Lewis RJ: Nodular angioblastic lymphoid hyperplasia with eosinophilia and lymphofolliculosis. Cutis 19:327-329, 1977.

20. Eady RAJ, Wilson-Jones E: Pseudopyogenic granuloma: enzyme histochemical and ultrastructural study: Hum Pathol 8:653-668, 1977.

21. Rosai J, Gold J, Landy R: The histiocytoid hemangiomas: a unifying concept embracing several previously described entities of the skin, soft tissue, large vessels, bone, and heart. Hum Pathol 10:707-730, 1979.

22. Chang T, Chen C: Eosinophilic granuloma of lymph nodes and soft tissue. China Med 81:344, 1962.

23. Weber L, Blanke H, Rodermund OE: Bullose angiolymphoide Hyperplasie mit Eosinophilie. Hautarzt 33: 411-415, 1982.

24. Enzinger FM, Weiss SW: Soft tissue tumors. St. Louis, C.V. Mosby, pp 391-397, 1983.

25. Buchner A, Silverman S Jr, Wara WM, Hansen LS: Angiolymphoid hyperplasia with eosinophilia (Kimura's disease). Oral Surg 49:309-313, 1980.

26. Castro C, Winkelmann RK: Angiolymphoid hyperplasia with eosinophilia in the skin. Cancer 34:1696-1705, 1974.

27. Nelson DA, Jarratt M: Angiolymphoid hyperplasia with eosinophilia. Pediatr Dermatol 1:210-214, 1984.

28. Peters $E$, Altini $M$, Kola $A H$ : Oral angiolymphoid hyperplasia with eosinophilia. Oral Surg 61:73-79, 1986.

29. Rosai J: Angiolymphoid hyperplasia with eosinophilia of the skin: its nosological position in the spectrum of histiocytoid hemangioma. Am J Dermatopathol 4:175-184, 1982.

30. Iguchi $\mathrm{Y}$, Inoue $\mathrm{T}$, Shimono $\mathrm{M}$, Yamamura $\mathrm{T}$, Shigematsu T, Takahashi S: Kimura's disease and its relation to angiolymphoid hyperplasia with eosinophilia: report of three cases and review of the literature. J Oral Pathol $15: 132-137,1986$.

31. Kung ITM, Gibson JB, Banatyne PM: Kimura's disease: a clinicopathological study of 21 cases and its distinction from angiolymphoid hyperplasia with eosinophilia. $P a-$ thology 16:39-44, 1984

32. Kohno $Y$ : So-called eosinophilic granuloma of the soft 
tissue; report of a case. Study in comparison with angiolymphoid hyperplasia with eosinophilia. Jpn J Oral Maxillofac Surg 27:445-453, 1981.

33. Kawahara F, Tanaka K, Yoshimura M, Hieda T, Kameyama T, Suzaku C: A case of eosinophilic granuloma of the soft tissue, so-called Kimura's disease. J Jap Stomatol Soc 31:205-207, 1982

34. Hamrick HJ, Jennette C, LaForce CF: Kimura's disease: report of a pediatric case in the United States. $J$ Allergy Clin Immunol 73:561-566, 1984.

35. Henry PG, Burnett JW: Angiolymphoid hyperplasia with eosinophilia. Arch Dermatol 114:1168-1172, 1978.

36. Botet MV, Sanchez JL: Angiolymphoid hyperplasia with eosinophilia: report of a case and a review of the literature. J Dermatol Surg Oncol 4:931-936, 1978.

37. Saxe N, Kahn LB: Angiolymphoid hyperplasia with eosinophilia. S Afr Med J 52:454-457, 1977.

38. Dickens JRE: Pathologic quiz case one. Arch Otolaryngol 103:624-625, 1977.

39. Buckerfield JB, Edwards MB: Angiolymphoid hyperplasia with eosinophilia in oral mucosa. Oral Surg 47: 539-544, 1979.

40. Eveson JW, Lucas RB: Angiolymphoid hyperplasia with eosinophilia. J Oral Pathol 8:103-108, 1979.

41. Eisenberg E, Lowlicht R: Angiolymphoid hyperplasia with eosinophils: a clinical-pathological conference. $J$ Oral Pathol 14:216-223, 1985.

42. Massa MC, Fretzin DF, Chowdhury L, Sweet DL: Angiolymphoid hyperplasia demonstrating extensive skin and mucosal lesions controlled with vinblastine therapy. $J$ Am Acad Dermatol 11:333-339, 1984.

43. Kuo T-T, Hsueh S, Su I-J, Gonzalez-Crussi F, Chen J-S: Histiocytoid hemangioma of the heart with peripheral eosinophilia. Cancer 55:2854-2861, 1985.

44. Rao RN, Spurlock BO, Witherington R: Angiolymphoid hyperplasia with eosinophilia: report of a case with penile lesions. Cancer 47:944-949, 1981.

45. Moesner J, Pallesen R, Sorensen B: Angiolymphoid hyperplasia with eosinophilia (Kimura's disease). A case with dermal lesions in the knee region and a popliteal arteriovenous fistula. Arch Dermatol 117:650-653, 1981.

46. Hendricks MW, Moore MM, Dell PC: Angiolymphoid hy. perplasia with eosinophilia: a case report. J Hand Surg 10:286-288, 1985

47. White RE, Agudelo CA: Digital gangrene in a patient with angiolymphoid hyperplasia with eosinophilia. $J$ Rheumatol 13:234-235, 1986.

48. Burrall BA, Barr RJ, King DF: Cutaneous histiocytoid hemangioma. Arch Dermatol 118:166-170, 1982.

49. Howell GE, Heckler FR: Angiolymphoid hyperplasia with eosinophilia. Ann Plast Surg 9:333-336, 1982.

50. Ose D, Vollmer R, Shelburne J, McComb R, Harrelson J Histiocytoid hemangioma of the skin and scapula. A case report with electron microscopy and immunohistochemistry. Cancer 51:1656-1662, 1983.

51. Kung TM, Gibson JB, Bannatyne PM: A clinicopathological study of 21 cases and its distinction from angiolym- phoid hyperplasia with eosinophilia. Pathology 16:3944,1984 .

52. Starzycki Z: Angiolymphoid hyperplasia with eosinophilia (choroba Kimury). Przegl Dermatol 69:275-282, 1982.

53. Hirashima M, Sakata K, Tashino K, Ohmori J, Iyama K, Tsuda H, Nagai T, Hiraoka T, Kimura T: Spontaneous production of eosinophil chemotactic factors by $\mathrm{T}$ lym. phocytes from patients with subcutaneous angioblastic lymphoid hyperplasia with eosinophilia. Clin Immunol Immunopathol 39:231-241, 1986.

54. Takenaka T, Okuda M, Usami A, Kawabori S, Ogami Y, Kubo K, Uda $\mathrm{H}$ : Histological and immunological studies on eosinophilic granuloma of soft tissue, so-called Kimu. ra's disease. Clin Allergy 6:27-39, 1976

55. Barnes L, Koss W, Nieland ML: Angiolymphoid hyperplasia with eosinophilia: a disease that may be confused with malignancy. Head Neck Surg 2:425-434, 1980.

56. Grimwood R, Swinehart JM, Aeling JL: Angiolymphoid hyperplasia with eosinophilia. Arch Dermatol 115:205207, 1979 .

57. Albers HJ: Angiolymphoide Hyperplasie, ein erfolgreich behandelter Fall. Z Hautkr 61:47-49, 1986.

58. Baler GR: Angiolymphoid hyperplasia with eosinophilia. $J$ Dermatol Surg Oncol 7:229-234, 1981.

59. Alsina M, Ferrabdo J, Lecha M, Palou J, Mascaro JM: Respuesta terapeutica de la hiperplasia angiolinfoide al tratamiento con acido retinoico aromatico. Med Cutan Iber Lat Am 12:519-524, 1984.

60. Gardner JH, Amonette RA, Chesney TM: Angiolymphoid hyperplasia with eosinophilia. I Dermatol Surg Oncol $7: 414-418,1981$

61. Streinzer W, Chott A, Zrunek M, Hartenau F: Angiolymphoide Hyperplasie mit Eosinophilie (Kimura's Disease). Laryngol Rhinol Otol 64:342-346, 1985

62. Thompson JW, Colman M, Williamson C, Ward PH: Angiolymphoid hyperplasia with eosinophilia of the external ear canal. Arch Otolaryngol 107:316-319, 1981.

63. Eriandson RA: Diagnostic immunohistochemistry of human tumor. Am J Surg Pathol 8:615-624, 1984.

64. Weiss SW, Enzinger FM: Epithelioid hemangioendothelioma - a vascular tumor often mistaken for a carcinoma. Cancer 50:970-981, 1982.

65. Nadji M: Immunoperoxidase techniques II. Application to cutaneous neoplasms. Am $J$ Dermatopathol 8:124-129, 1986 .

66. Marsden ATH: Lympho-eosinophilic granuloma, an unknown disease. In: Fourth Proceedings of the International Academy of Oral Pathology. Johannesburg, Gordon \& Breach, p. 128, 1969.

67. Rehak A, Bou-Resli M, Mousa AM, Al-Zaid NS: Angiolymphoid hyperplasia with eosinophilia. An electron microscopy study. Dermatologica 161:157-166, 1980.

68. Daniels DG, Schrodt R, Fliegelman MT, Owen LG: Ultrastructural study of a case of angiolymphoid hyperplasia with eosinophilia. Arch Dermatol 109:870-872, 1974.

69. Bonnetblanc JM Bernard P, Malinvaud G: Treatment of angiolymphoid hyperplasia with eosinophilia. $J \mathrm{Am}$ Acad Dermatol 13:668-669, 1985. 